\title{
Corticosteroids in management of anaphylaxis; a systematic review of evidence
}

${ }^{1}$ Department of Pharmacology, Faculty of Medicine, University of Colombo, Sri Lanka

${ }^{2}$ Department of Surgery, Faculty of Medicine, University of Colombo, Sri Lanka

${ }^{3}$ Department of Clinical Immunology, Royal Free Hospital, London, UK

Work was carried out at Department of Pharmacology, Faculty of Medicine, University of Colombo, Sri Lanka

\section{KEY WORDS}

Anaphylaxis; emergency management; corticosteroids; prednisolone; allergy

\section{Corresponding author}

Chiranthi Kongala Liyanage

Department of Pharmacology,

Faculty of Medicine

University of Colombo

25, Kinsey road, Colombo 08, Sri Lanka

Phone: +94112697 483, +94772330362

Fax: +94 112697483

E-mail: chiranthiliyanage@gmail.com

\section{Doi}

10.23822/EurAnnACI.1764-1489.15

\author{
Abbreviations \\ ED, Emergency department; IgE, \\ Immunoglobulin E; IL-6, Interleukin 6; \\ IL-33, Interleukin 33; PAF, Platelet \\ activating factor; RCT, Randomized control \\ trial; TNF $\alpha$, Tumor necrosis factor $\alpha$.
}

\begin{abstract}
Summary
As anaphylaxis is a medical emergency, there are no randomized controlled clinical trials on its emergency management. Therefore, current guidelines are mostly based on data from observational studies, animal and laboratory studies. Although epinephrine is the mainstay of recommended treatment, corticosteroids are also frequently used. This review evaluates the evidence on the use of corticosteroids in emergency management of anaphylaxis from published human and animal or laboratories studies. Thirty original research papers were found with 22 human studies and eight animal or laboratory studies. The average rate of corticosteroid use in emergency treatment was $67.99 \%$ (range $48 \%$ to 100\%). Corticosteroids appear to reduce the length of hospital stay, but did not reduce revisits to the emergency department. There was no consensus on whether corticosteroids reduce biphasic anaphylactic reactions. None of the human studies had sufficient data to compare the response to treatment in different treatment groups (i.e. corticosteroids, epinephrine, antihistamines). Animal studies demonstrated that corticosteroids act through multiple mechanisms. These modulate gene expression, with effects becoming evident 4 to 24 hours after administration. A much quicker response has been detected within 5 to 30 minutes, through blockade of signal activation of glucocorticoid receptors independent of their genomic effects. Therefore, we conclude that there is no compelling evidence to support or oppose the use of corticosteroid in emergency treatment of anaphylaxis. However, based on the available data, it appears to be beneficial and there was no evidence of adverse outcomes related to the use of corticosteroids in emergency treatment of anaphylaxis.
\end{abstract}

\section{Introduction}

Anaphylaxis is a "serious, generalized or systemic acute immunologic reaction" that is "rapid in onset and that would be fatal or life threatening" (1-3). Based on available data from international studies, the life-time prevalence of anaphylaxis has been estimated at 0.05 to $2 \%$ (4), with an estimated incidence ranging from 10 to 20/100,000 population per year (5-7). The incidence of anaphylaxis is also reportedly increasing worldwide, particularly food-induced anaphylaxis $(8,9)$.
Anaphylaxis is brought about by direct or indirect activation of mast cells. Anaphylaxis classically involves the skin (80\%), respiratory $(70 \%)$, gastrointestinal $(30-45 \%)$, cardiovascular (10-45\%) and central nervous (10-15\%) systems (2,6,10-12). Symptoms generally appear suddenly, progress over minutes to hours and increase in severity. Although only one organ system may be initially involved, symptoms will typically progress to eventually involve at least two organ systems $(13,14)$. The diagnosis of anaphylaxis relies heavily on clinical judgment due to 
the lack of availability of rapid diagnostic tests $(13,15)$. Therefore, given the heterogeneity of presentation, there are widespread concerns regarding under diagnosis, under reporting and inadequate treatment of anaphylaxis and non-adherence to management guidelines (16-18).

As anaphylaxis is a medical emergency, conducting randomised control trials (RCT) on treatment of anaphylaxis is practically and ethically problematic. A Cochrane review published in 2013 concluded that there is no evidence from high quality studies for the use of steroids in the emergency management of anaphylaxis (19). The evidence base underpinning the currently recommended first-line of treatment epinephrine is also based on observational studies and extrapolated from laboratory studies. Although not as robust as evidence from RCTs, a systematic analysis of published data on other treatment modalities in the emergency management of anaphylaxis could lead to beneficial inferences.

\section{Pathogenesis of anaphylaxis}

The underlying pathogenesis of classical anaphylaxis involves IgE, synthesized in response to exposure to an allergen, becoming fixed to a high affinity receptors for IgE (FcERI receptors) on the surface membranes of mast cells and basophils (11). On re-exposure to the same allergen, receptor-bound IgE molecules aggregate and results in cell activation. Activation of multiple tyrosine kinases (i.e. Lyn, Syk, and Fyn) with both positive and negative regulatory responses on the signal transduction cascade (20) leads to calcium influx in to the cells leading to cell degranulation $(21,22)$. Mast cells and basophils release preformed chemical mediators and those that are synthesized de novo. Preformed mediators include histamine, tryptase, carboxypeptidase $\mathrm{A}$, and proteoglycans. Inflammatory cytokines, such as IL-6, IL$33(21,22)$ and TNF- $\alpha$, a late-phase mediator are also released from mast cells as preformed mediators. Downstream activation of phopholipase A2 (PLA2), cyclooxygenases and lipoxygenases, leads to the production of arachidonic acid metabolites such as leukotrienes, prostaglandins and platelet activating factor (PAF). Furthermore, IgE enhances expression of FceRI receptors on mast cells and basophils and increases the intensity of anaphylaxis.

In addition to this, non-IgE mediated mechanisms have also been implicated in anaphylaxis. IgG mediated anaphylaxis has been reported due to triggers such as high molecular weight iron dextran, infusion of chimeric and therapeutic monoclonal antibodies such as infliximab $(23,24)$. Hemodialysis, liposomal drugs, polyethylene glycols and heparin contaminated with over sulfated chondroitin sulfate have been reported to cause complement-mediated anaphylaxis by generation of kallikrein, bradykinin, and complement protein-derived anaphylatoxins C3a and C5a (25). Factor XII and the coagulation system are also postulated to be involved. There could also be a direct activation of the innate immune system triggering anaphylaxis as in peanut allergies (26). Idiopathic anaphylaxis has been described in some individuals in whom FceRI receptors may aggregate through autoimmune mechanisms (27). The mechanism by which certain triggers such as exercise, cold air or water exposure and radiation induce anaphylaxis is not yet fully understood. Irrespective of the initiating mechanism, mast cells and basophils play a central role in mediating an anaphylactic reaction. The release of cellular mediators leads to end-organ responses in the skin, respiratory tract, cardio-vascular system, gastrointestinal tract and perhaps the nervous system (14). Most anaphylactic reactions are uniphasic. However, additional patterns of reactions have been described i.e. delayed onset, biphasic reactions and protracted or persistent reactions (28). In biphasic reactions, the initial reaction is followed by a relatively symptom-free period and the symptoms recur, often in a more severe and refractory to therapy form (29). The exact mechanism involved in each of these patterns is not yet fully understood.

\section{Guidelines on treatment of anaphylaxis}

Currently, the recommended mainstay of therapy in the event of an anaphylaxis is epinephrine given either intramuscularly or intravenously in specialist settings (14,30-33). It counters most of the pathophysiogical processes giving rise to anaphylaxis $(11,34)$. Second-line treatments include corticosteroids, $\mathrm{H} 1$ - and $\mathrm{H} 2$-antihistamines, and bronchodilators. Unlike with epinephrine, there are differing recommendations regarding the use of glucocorticoids and other additional therapies in emergency management of anaphylaxis (35). Recommended emergency treatment of anaphylaxis according to recent guidelines is summarized in table $\mathbf{1}$.

The American (13) guidelines state that there is no place for glucocorticoids in emergency management of anaphylaxis. The British (36), European (30), Australasian (33), Canadian (37) and the World Allergy Organisation (31) guidelines recommend glucocorticoids as a second-line / adjuvant therapy after initial treatment with adrenaline and acknowledge the lack of robust evidence to support this practice $(13,30,31,38)$. The recommended type, route, dose and duration of therapy of glucocorticoids are also varied. Prednisolone, methylprednisolone, dexamethasone and hydrocortisone administered orally, intravenously or intramuscularly are advocated in different guidelines (35). These are given as a single dose or continued for few days as a short course after the initial event $(2,35,39)$.

\section{Mechanism of action of glucocorticoids in anaphylaxis}

The use of glucocorticoids in anaphylaxis is supported by the logical deduction of how the mechanism of action of glucocor- 
Table 1 - Summary guidelines on emergency management of anaphylaxis.

\begin{tabular}{|c|c|c|c|c|c|c|}
\hline \multirow{2}{*}{$\begin{array}{l}\text { Organisation, } \\
\text { country, year } \\
\text { of publication, } \\
\text { reference }\end{array}$} & \multirow{2}{*}{$\begin{array}{l}\text { First line } \\
\text { of therapy, } \\
\text { route }\end{array}$} & \multicolumn{4}{|c|}{ Glucocorticoids } & \multirow[b]{2}{*}{ Other therapies } \\
\hline & & Recommendation & Type & $\begin{array}{l}\text { Route, } \\
\text { dose }\end{array}$ & Dose & \\
\hline $\begin{array}{l}\text { World Allergy } \\
\text { Organization, } \\
2015\end{array}$ & $\begin{array}{l}\text { Adrenaline, } \\
\text { IM }\end{array}$ & $\begin{array}{l}\text { To prevent bipha- } \\
\text { sic reactions. No } \\
\text { effect on initial } \\
\text { symptoms }\end{array}$ & Not given & Not given & Not given & $\begin{array}{l}\text { Second or third-line: H1 } \\
\text { antihistamines, } \\
\text { H2-antihistamines }\end{array}$ \\
\hline $\begin{array}{l}\text { Australasian } \\
\text { Society of Clinical } \\
\text { Immunology and } \\
\text { Allergy (ASCIA), } \\
\text { Australia, 2015 }\end{array}$ & $\begin{array}{l}\text { Adrenaline, } \\
\text { IM }\end{array}$ & Adjuvant & Prednisolone & Oral & $\begin{array}{l}1 \mathrm{mg} / \mathrm{kg} \\
\text { maximum } \\
50 \mathrm{mg} \text { daily }\end{array}$ & $\begin{array}{l}\text { Glucagon, metaraminol, } \\
\text { vasopressin }\end{array}$ \\
\hline \multirow{2}{*}{$\begin{array}{l}\text { European } \\
\text { Academy } \\
\text { of Allergy } \\
\text { and Clinical } \\
\text { Immunology, } \\
2014\end{array}$} & \multirow{2}{*}{$\begin{array}{l}\text { Adrenaline, } \\
\text { IM }\end{array}$} & \multirow[t]{2}{*}{ Third-line } & Not given & Systemic, & Not given & \multirow{2}{*}{$\begin{array}{l}\text { Second-line: inhaled } \\
\text { short-acting beta-2 } \\
\text { agonists; Third-line: } \\
\text { Oral H1- (and H2)- } \\
\text { antihistamines }\end{array}$} \\
\hline & & & Budesonide & $\begin{array}{l}\text { Nebu- } \\
\text { lized }\end{array}$ & Not given & \\
\hline \multirow{2}{*}{$\begin{array}{l}\text { American } \\
\text { Academy of } \\
\text { Allergy, Asthma } \\
\text { and Immunology } \\
\text { (AAAAI) and the } \\
\text { American College } \\
\text { of Allergy, Asthma } \\
\text { and Immunology } \\
\text { (ACAAI), USA, } \\
2014\end{array}$} & \multirow[t]{2}{*}{$\begin{array}{l}\text { Adrenaline, } \\
\text { IM }\end{array}$} & \multirow{2}{*}{$\begin{array}{l}\text { Adjuvant, not } \\
\text { effective in the } \\
\text { acute management } \\
\text { of anaphylaxis }\end{array}$} & $\begin{array}{l}\text { Methylprednis- } \\
\text { olone }\end{array}$ & $\begin{array}{c}\text { Intrave- } \\
\text { nous }\end{array}$ & 1 to $2 \mathrm{mg} / \mathrm{kg}$ & \multirow[t]{2}{*}{$\begin{array}{l}\text { glucagon, b-agonist, } \mathrm{H} 1 \\
\text { and/or } \mathrm{H} 2 \text { antihistamines }\end{array}$} \\
\hline & & & Prednisone & Oral & $\begin{array}{l}1 \mathrm{mg} / \mathrm{kg} \text {, up } \\
\text { to } 50 \mathrm{mg}\end{array}$ & \\
\hline \multirow[t]{2}{*}{$\begin{array}{l}\text { Canadian Pae- } \\
\text { diatric Society, } \\
\text { Canada, } 2010\end{array}$} & \multirow[t]{2}{*}{$\begin{array}{l}\text { Adrenaline, } \\
\text { IM }\end{array}$} & \multirow[t]{2}{*}{ Second-line } & Prednisone & Oral & $\begin{array}{l}1 \mathrm{mg} / \mathrm{kg} \mathrm{PO} \\
\text { (maximum } \\
75 \mathrm{mg} \text { ) }\end{array}$ & \multirow{2}{*}{$\begin{array}{l}\text { second-line } \\
\text { agents: cetirizine, } \\
\text { diphenhydramine, } \\
\text { ranitidine, salbutamol, } \\
\text { glucagon }\end{array}$} \\
\hline & & & $\begin{array}{l}\text { Methylprednis- } \\
\text { olone }\end{array}$ & $\begin{array}{l}\text { Intrave- } \\
\text { nously }\end{array}$ & $\begin{array}{c}1 \mathrm{mg} / \mathrm{kg} \mathrm{IV} \\
(\text { maximum } \\
125 \mathrm{mg})\end{array}$ & \\
\hline $\begin{array}{l}\text { Working Group of } \\
\text { the Resuscitation } \\
\text { Council, UK, } \\
2008\end{array}$ & $\begin{array}{l}\text { Adrenaline, } \\
\text { IM }\end{array}$ & Second-line & Hydrocortisone & $\begin{array}{l}\text { Slow } \\
\text { intrave- } \\
\text { nous or } \\
\text { intramus- } \\
\text { cular }\end{array}$ & $200 \mathrm{mg}$ & $\begin{array}{l}\text { Adjuvant therapies: } \\
\text { salbutamol (inhaled } \\
\text { or IV), ipratropium } \\
\text { (inhaled), aminophylline } \\
\text { (IV) or magnesium (IV). } \\
\text { When initial resuscitation } \\
\text { with adrenaline and } \\
\text { fluids has not been } \\
\text { successful: noradrenaline, } \\
\text { vasopressin, metaraminol } \\
\text { and glucagon }\end{array}$ \\
\hline
\end{tabular}


ticoids counteracts the pathophysiological processes in anaphylaxis. It is also drawn from evidence of their efficacy in treatment of diseases mediated by similar immunological responses such as asthma $(40,41)$. An illustration of the mechanism of glucocorticoids in anaphylaxis is given in figure $\mathbf{1}$.

Glucocorticoids are potent inhibitors of inflammatory processes and potent anti-allergic compounds reducing the number, maturation and activation of mast cell, which play a central role in anaphylaxis (42-44). They act through modulation of gene expression, and therefore require 4 to 6 hours for the effects to manifest (45). These anti-inflammatory effects are mediated by direct binding of the glucocorticoid / glucocorticoid receptor complex to specific elements in the promoter region of genes, or by interacting with other transcription factors such as the activating protein-1 or nuclear factor-kappa B $(40,41,46)$. For example, in the mast cells, glucocorticoids down-regulate transcription of pro-inflammatory molecules such as cytokines, chemokines, arachidonic acid metabolites and directly regulate multiple signaling and adaptor molecules (47). These genomic effects of glucocorticoids are relatively delayed with the maximal effect being detected at 2 hours (48). Thus, seemingly little evidence supports their use in emergency management of anaphylaxis, as many aspects of glucocorticoids action were initially thought to be both time and transcription-dependent.

However, recent studies have shown that glucocorticoids also exert rapid non-genomic effects, which can be non-specific or specific $(10,49,50)$, brought about by membrane interactions at high concentration (51) or mediated by interactions with intracellular receptors or membrane-bound receptors $(52,53)$. In some cases, these are thought to be mediated through the classical steroid receptor that functions as a ligand-activated transcription factor. Two animal studies have shown that glucocorticoids have detectable inhibitory effects on anaphylaxis within 5 to 30 minutes, mostly through blockade of these glucocorticoid

Figure 1 - Pathogenesis of anaphylaxis and mechanism of action of glucocorticoids.

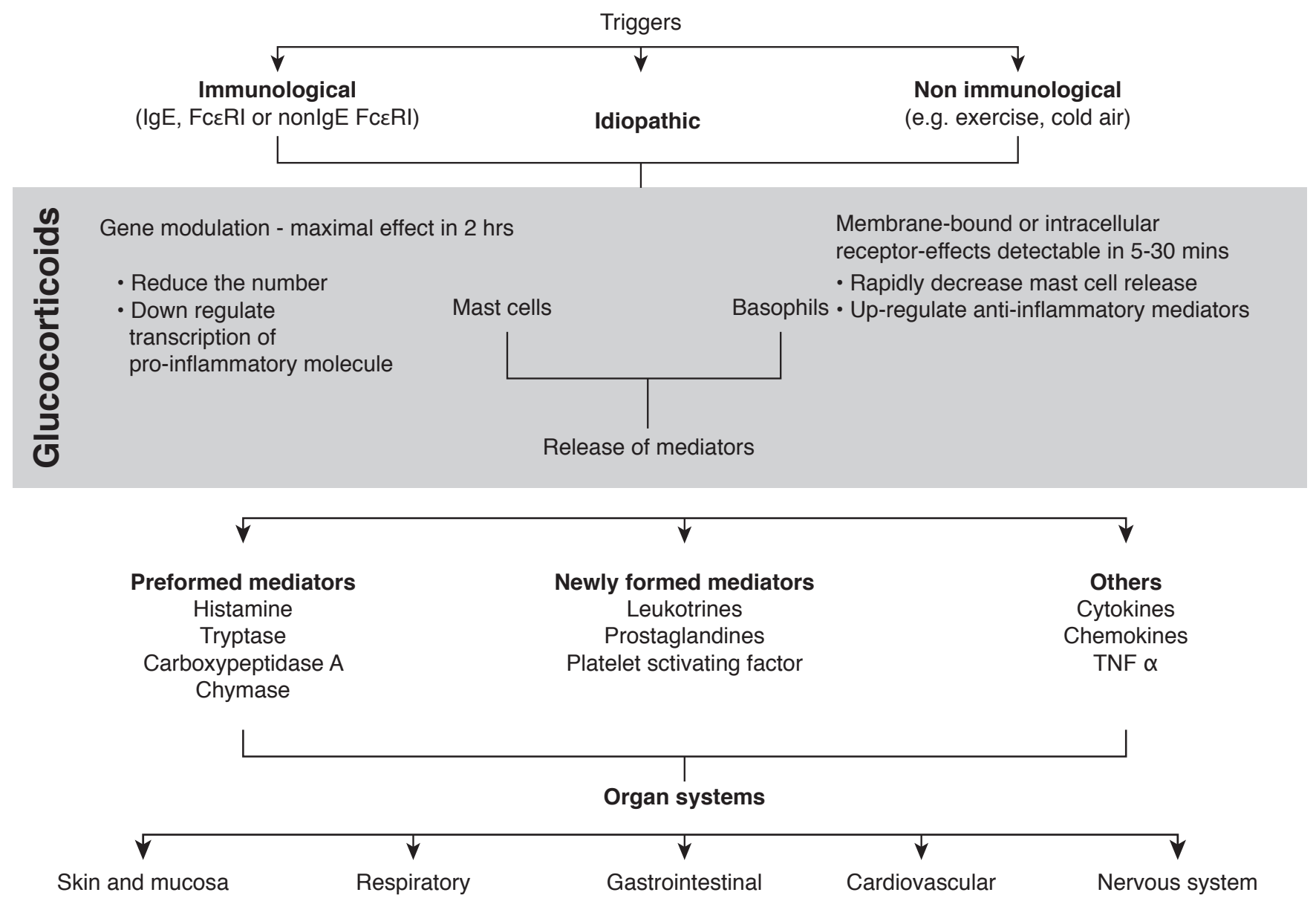


Figure 2 - Summary of search strategy and results.

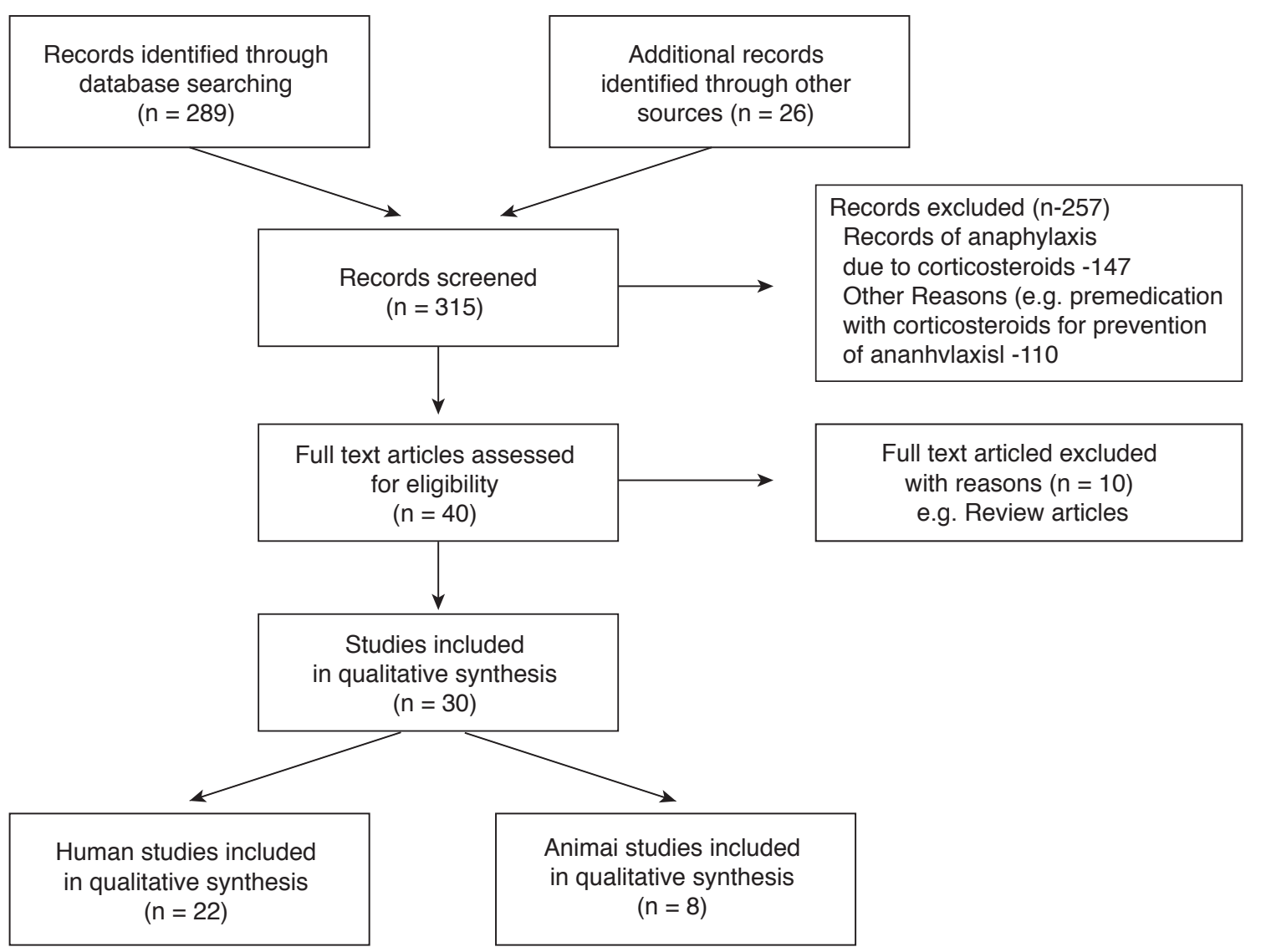

receptors $(52,53)$. There are diverse rapid effects of glucocorticoids, ranging from activation of adenylyl cyclase, mitogen-activated protein kinases (MAPKs), guanosine triphosphate-binding proteins, and protein kinase C (54). Glucocorticoids rapidly decrease histamine release from the mast cell surface and up-regulate anti-inflammatory mediators $(46,49,55)$.

The lack of concrete evidence and the ethical and practical difficulties in conducting randomised control trials on acute management anaphylaxis is challenging for researchers and clinicians alike. This paper aims to review and systematically document the evidence on the use of corticosteroids in emergency treatment of anaphylaxis and identifies clinical research priorities.

\section{Search strategy}

Searched libraries included Pubmed / Medline from inception to March 2016. Additional references were found through cross-references from articles and reviews. The key words used included anaphylaxis, allergy, hypersensitivity, corticosteroids, glucocorticoids, steroids, dexamethasone, hydrocortisone, pred- nisolone. Human and animal studies on glucocorticoids for management of allergy or anaphylaxis in peer-review journals were included. The search was refined by language (English).

\section{Results}

The original search found 289 articles in PubMed (figure 2). Twenty-six additional articles were identified through other sources. However, 147 of these were found to be on anaphylaxis due to corticosteroids. There were 28 relevant original research papers reviewed with 22 human studies and 8 animal or laboratory studies. The human studies included 19 retrospective cohort studies, one cross sectional descriptive study and two prospective cohort studies.

\section{Use of corticosteroids in anaphylaxis: human studies}

The relevant papers on human studies are summarised in table 2 . The rate of corticosteroid use in emergency treatment of anaphylaxis varied from $48 \%$ to $100 \%$ with an average of $67.99 \%$. 
Biphasic anaphylactic reactions were reported in approximately $2.2 \%$ to $8.7 \%$ of patients reporting to emergency departments $(56,57)$. A study conducted in a tertiary care hospital in Canada has found that those who develop biphasic reactions are less likely to have received epinephrine or corticosteroids during emergency management (58). However, three other studies have not found a significant difference in emergency treatment with either epinephrine or steroids in those with or without biphasic reactions $(56,59)$. There is some evidence suggesting that the length of hospital stay tends to be shorter in those treated with corticosteroids for anaphylaxis (60). However, it has not been found to reduce the revisits to the emergency department with anaphylaxis or other unrelated causes (61). None of the human studies had sufficient data to comment on the response

Table 2 - Use of corticosteroids in anaphylaxis; human studies.

\begin{tabular}{|c|c|c|c|c|c|c|}
\hline $\begin{array}{l}\text { Author, } \\
\text { country, year }\end{array}$ & Study group & Study type & $\begin{array}{c}\text { Percentage } \\
\text { treated with } \\
\text { steroids }\end{array}$ & Study objective & $\begin{array}{l}\text { Findings relevant } \\
\text { to cortisteroids }\end{array}$ & Study weakness \\
\hline \multirow{2}{*}{$\begin{array}{l}\text { Michelson KA } \\
\text { et al., USA, } \\
2015\end{array}$} & \multirow{2}{*}{$\begin{array}{c}5203 \text { patients } \\
\text { (aged } 1 \text { month } \\
\text { to } 18 \text { years) } \\
\text { presenting to } \\
\text { emergency } \\
\text { departments at } 35 \\
\text { hospitals }\end{array}$} & \multirow{2}{*}{$\begin{array}{l}\text { Retrospective } \\
\text { cohort study }\end{array}$} & \multirow{2}{*}{75.9} & \multirow{2}{*}{$\begin{array}{l}\text { Association between } \\
\text { glucocorticoid } \\
\text { treatment and } \\
\text { length of hospital } \\
\text { stay and parenteral } \\
\text { epinephrine beyond } \\
\text { the first hospital day }\end{array}$} & $\begin{array}{l}\text { Glucocorticoid } \\
\text { administration was } \\
\text { associated with lower } \\
\text { odds of epinephrine } \\
\text { administration beyond } \\
\text { the first hospital day }\end{array}$ & \\
\hline & & & & & $\begin{array}{l}\text { Glucocorticoid use } \\
\text { was not associated } \\
\text { with less revisits to the } \\
\text { emergency department }\end{array}$ & \\
\hline $\begin{array}{l}\text { Grunau BE et } \\
\text { al., Canada, } \\
2015\end{array}$ & $\begin{array}{l}2701 \text { patient } \\
\text { with a discharge } \\
\text { diagnosis code of } \\
\text { "allergic reaction". } \\
\text { Patients younger } \\
\text { than } 17 \text { years of } \\
\text { age have been } \\
\text { excluded }\end{array}$ & $\begin{array}{l}\text { Retrospective } \\
\text { co hort study }\end{array}$ & 48 & $\begin{array}{c}\text { Number of } \\
\text { subsequent allergy- } \\
\text { related ED visits } \\
\text { within } 7 \text { days, all } \\
\text { cause mortality, the } \\
\text { number of clinically } \\
\text { important biphasic } \\
\text { reactions }\end{array}$ & $\begin{array}{l}\text { Steroid administration } \\
\text { does not prevent } \\
\text { emergency } \\
\text { department recidivism } \\
\text { within } 7 \text { days }\end{array}$ & $\begin{array}{c}\text { Data from only } 2 \\
\text { urban centers has } \\
\text { been included }\end{array}$ \\
\hline $\begin{array}{l}\text { Ko BS et al., } \\
\text { Korea, } 2015\end{array}$ & $\begin{array}{l}655 \text { patients } \\
\text { with anaphylaxis } \\
\text { admitted to } \\
\text { the emergency } \\
\text { department of a } \\
\text { tertiary teaching } \\
\text { hospital }\end{array}$ & $\begin{array}{l}\text { Retrospective } \\
\text { cohort study }\end{array}$ & 100 & $\begin{array}{l}\text { Epidemiology, } \\
\text { management, dispo- } \\
\text { sition, and clinical } \\
\text { out-comes }\end{array}$ & $\begin{array}{l}\text { Biphasic reaction } \\
\text { occurred in } 2.2 \% \text { of } \\
\text { the patients treated } \\
\text { with steroids }\end{array}$ & $\begin{array}{l}\text { Patients who have } \\
\text { not been treated } \\
\text { with steroids have } \\
\text { been excluded } \\
\text { from the study. }\end{array}$ \\
\hline
\end{tabular}




\begin{tabular}{|c|c|c|c|c|c|c|}
\hline $\begin{array}{l}\text { Author, } \\
\text { country, year }\end{array}$ & Study group & Study type & $\begin{array}{c}\text { Percentage } \\
\text { treated with } \\
\text { steroids }\end{array}$ & Study objective & $\begin{array}{l}\text { Findings relevant } \\
\text { to cortisteroids }\end{array}$ & Study weakness \\
\hline $\begin{array}{l}\text { Asia Y et al., } \\
\text { Canada, } 2014\end{array}$ & $\begin{array}{l}37,730 \text { patients } \\
\text { with anaphylaxis } \\
\text { visiting the } \\
\text { emergency } \\
\text { department of } \\
\text { a tertiary care } \\
\text { center }\end{array}$ & $\begin{array}{l}\text { Retrospective } \\
\text { cohort study }\end{array}$ & 68.1 & $\begin{array}{c}\text { Demographic } \\
\text { characteristics, } \\
\text { suspected triggers } \\
\text { and management of } \\
\text { anaphylaxis }\end{array}$ & $\begin{array}{c}\text { Higher percentage } \\
\text { of severe reactions } \\
(71.4 \%) \text { are treated } \\
\text { with steroids } \\
\text { compared to mild } \\
(50.0 \%) \text { and moderate } \\
(67.8 \%) \text { reactions. }\end{array}$ & $\begin{array}{l}\text { The outcome of } \\
\text { treatment is not } \\
\text { assessed }\end{array}$ \\
\hline $\begin{array}{l}\text { Worm et al., } \\
\text { Germany, } 2014\end{array}$ & $\begin{array}{c}3333 \text { cases of } \\
\text { anaphylaxis over } \\
\text { a } 3 \text { year period } \\
\text { from } 10 \text { European } \\
\text { countries }\end{array}$ & $\begin{array}{l}\text { Retrospective } \\
\text { record analysis } \\
\text { of one line data } \\
\text { registry }\end{array}$ & 60.4 & $\begin{array}{l}\text { Epidemiology, } \\
\text { symptomatology, } \\
\text { triggers, treatment }\end{array}$ & $\begin{array}{l}\text { No additional data } \\
\text { provided on steroid } \\
\text { use or outcomes }\end{array}$ & $\begin{array}{c}\text { There was no } \\
\text { comparison of } \\
\text { the outcome of } \\
\text { different treatment } \\
\text { modalities }\end{array}$ \\
\hline $\begin{array}{c}\text { Rappo et al. } \\
\text { Australia, } 2013\end{array}$ & $\begin{array}{c}34 \text { cases } \\
\text { anaphylaxis } \\
\text { due to tick bite } \\
\text { presenting an } \\
\text { an emergency } \\
\text { department }\end{array}$ & $\begin{array}{l}\text { Retrospective } \\
\text { cohort study }\end{array}$ & $97 \%$ & $\begin{array}{l}\text { Epidemiology, } \\
\text { symptomatology, } \\
\text { course of illness, } \\
\text { treatment }\end{array}$ & $\begin{array}{l}71 \% \text { were discharged } \\
\text { on oral prednisolone. } \\
\text { One }(4.1 \%) \text { of them } \\
\text { developed a biphasic } \\
\text { reaction }\end{array}$ & $\begin{array}{l}\text { Retrospective } \\
\text { medical record } \\
\text { review with a small } \\
\text { sample size. There } \\
\text { is no comparison of } \\
\text { the outcome among } \\
\text { the treatment groups }\end{array}$ \\
\hline \multirow[t]{2}{*}{$\begin{array}{l}\text { Hoffer et al., } \\
\text { Israel, } 2011\end{array}$} & \multirow{2}{*}{$\begin{array}{l}92 \text { children } \\
\text { admitted to a } \\
\text { single medical } \\
\text { center with the } \\
\text { diagnosis of } \\
\text { anaphylaxis }\end{array}$} & \multirow[t]{2}{*}{$\begin{array}{l}\text { Retrospective } \\
\text { cohort study }\end{array}$} & \multirow[t]{2}{*}{85} & \multirow{2}{*}{$\begin{array}{c}\text { Epidemiology, } \\
\text { symptomatology, } \\
\text { course of illness, } \\
\text { laboratory findings, } \\
\text { treatment, } \\
\text { concurrent illnesses }\end{array}$} & $\begin{array}{c}\text { Only } 72 \% \text { were } \\
\text { treated with } \\
\text { epinephrine }\end{array}$ & \multirow{2}{*}{$\begin{array}{l}\text { The outcome } \\
\text { of the different } \\
\text { treatment is not } \\
\text { analyzed }\end{array}$} \\
\hline & & & & & $\begin{array}{l}\text { 75\% received } \\
\text { antihistamines }\end{array}$ & \\
\hline $\begin{array}{l}\text { Orhan et al., } \\
\text { Turkey, } 2011\end{array}$ & $\begin{array}{l}224 \text { cases of } \\
\text { anaphylaxis } \\
\text { reported in } 137 \\
\text { children }\end{array}$ & $\begin{array}{l}\text { Retrospective } \\
\text { cohort study }\end{array}$ & 83.5 & $\begin{array}{l}\text { Epidemiology, } \\
\text { symptomatology, } \\
\text { course of illness, } \\
\text { treatment practices }\end{array}$ & $\begin{array}{c}\text { Only } 32.3 \% \text { received } \\
\text { epinephrine }\end{array}$ & \\
\hline $\begin{array}{l}\text { Sole et al., } \\
\text { Brazil, } 2011\end{array}$ & $\begin{array}{l}634 \text { patients from } \\
15 \text { Latin American } \\
\text { countries and } \\
\text { Portugal with } \\
\text { severe allergic } \\
\text { reactions }\end{array}$ & $\begin{array}{l}\text { Cross sectional } \\
\text { descriptive } \\
\text { study }\end{array}$ & 80.5 & $\begin{array}{l}\text { Epidemiology, } \\
\text { symptomatology, } \\
\text { triggers, course of } \\
\text { illness, treatment, } \\
\text { outcome }\end{array}$ & & $\begin{array}{l}\text { There is no } \\
\text { comparison } \\
\text { of outcome of } \\
\text { different treatment }\end{array}$ \\
\hline
\end{tabular}




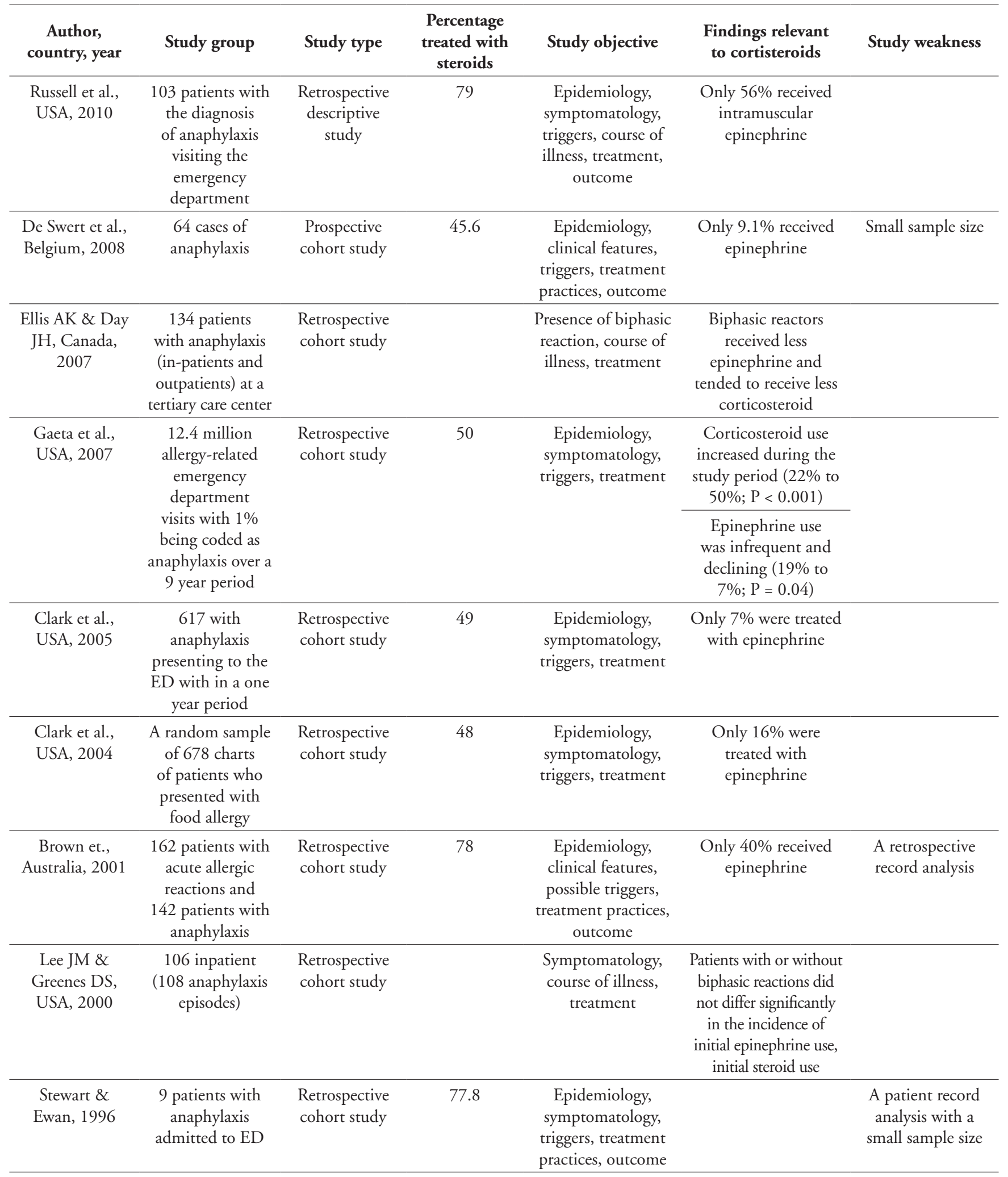


to treatment in different treatment groups (i.e. corticosteroids, epinephrine, antihistamines).

\section{Use of corticosteroids in anaphylaxis; animal and laboratory studies}

The findings of the relevant papers are summarized in table 3. The animal models used included guinea pigs (62-64) and mice $(48,53,65,66)$. One other study was conducted using A549 human adenocarcinoma cell line (52). Most investigated the effect of pretreatment with glucocorticoids. The postulated mechanisms of action include action through modulation of gene expression occurring 4 to 24 hours after treatment with glucocorticoids $(48,65)$ and blockade of signal activation of glucocorticoid receptors independent of its genomic effects $(52,53)$. The latter response has been detectable within 5 to 30 minutes $(52,53)$. Interestingly, prednisolone has been found to inhibit passive cutaneous anaphylaxis in a biphasic manner at 8-12 and 24 hours (48).

\section{Discussion}

Anaphylaxis is an acute immunologic reaction due to direct or indirect activation of mast cells. Prompt definitive management can be life saving, and any delays may result in a fatal outcome. Irrespective of the trigger, management of anaphylaxis is the same for all patients. Although epinephrine is clearly recommended as the first line treatment for management of anaphylaxis, human studies reviewed here revealed that usage of epinephrine either during pre-hospital or emergency care varies widely from $7-70 \%(12)$. This could be due to over-prudent hesitancy to administer epinephrine with the fear of serious adverse effects. Conversely, there is a lower threshold to initiate glucocorticoid therapy in patients with anaphylaxis. Despite the lack of any strong recommendations, $45-97 \%$ of the patients receive glucocorticoids in emergency management of anaphylaxis $(16,39,67,68)$. Some multicenter trials have demonstrated that corticosteroids are still being administered as the first-line therapy instead of epinephrine $(17,18,39)$.

When considering the pathogenesis of anaphylaxis and the mechanism of action of glucocorticoids, it becomes evident that glucocorticoids have a theoretical benefit in treatment of anaphylaxis. For many years, glucocorticoids were thought to act through nuclear receptors by modulating gene expression, hence having delayed onset of action. However, recent advancements have demonstrated that glucocorticoids induce a rapid anti-inflammatory effect by a non-genomic mechanism, acting through membrane-bound or cytosolic receptors. Laboratory studies have demonstrated a detectable response in as little as 5 minutes from the point of administration.
Most cases of anaphylaxis resolved after initial treatment. One to $20 \%$ will develop a biphasic reaction, a delayed recurrence of illness occurring hours after improvement of the symptoms $(59,61,69)$. There are multiple factors that have been described to be associated with biphasic reactions including under-treatment and delay in treatment $(58,59)$. The World Allergy Organisation recommends the administration of glucocorticoids to prevent such biphasic reactions, and states that there are no or minimal effects on initial symptoms (31). This is supported by laboratory studies, which demonstrate that prednisolone inhibits passive cutaneous anaphylaxis in a biphasic manner. However, except for one retrospective cohort study, none of the other human studies found that glucocorticoids lower the incidence or prevents the progression of symptoms.

Although observational studies reveal that those with more severe reactions are more likely to be given corticosteroids, there is no conclusive evidence to infer that early administration of corticosteroids prevents progression of symptoms $(56,70)$. Additional benefits such as shortening the length of hospital stay and reducing the need to repeated epinephrine injections have also been attributed to glucocorticoid therapy in anaphylaxis. A major limitation in the human studies included in this review is the lack of data on the outcome of patients by the treatment received in the emergency department to make a meaningful comparison between treatment groups.

\section{Conclusions}

Corticosteroids are often used in the management of anaphylaxis and sometimes used as a first-line therapy instead of adrenaline, despite the lack of compelling evidence and guidelines recommending their use only as an adjuvant therapy. There are no randomised or quasi-randomised trials providing support to this practice. Nevertheless, the pathophysiological basis of anaphylaxis and the mechanism of action of glucocorticoids, particularly the recent evidence of the rapid non-genomic effects provide a rational basis for using corticosteroids in the emergency treatment of anaphylaxis. However, there is no concrete evidence to support or oppose the use of corticosteroids in emergency management of anaphylaxis, particularly as short-term use of glucocorticoids is seldom associated with serious adverse effects (71). Therefore, based on the animal / laboratory studies and human studies reviewed, we conclude that use of glucocorticoids along with administration of epinephrine in the emergency management of anaphylaxis is rational and may be beneficial. Although RCT may not being plausible, more evidence is needed on treatment and treatment outcomes through at least prospective cohort studies. These could provide valid data to evaluate the definitive place of glucocorticoids in the emergency management of anaphylaxis. 
Table 3 - Use of corticosteroids in anaphylaxis; animal studies.

\begin{tabular}{|c|c|c|c|}
\hline $\begin{array}{l}\text { Author, Country, } \\
\text { Year }\end{array}$ & Animal model & Study objective & Findings \\
\hline $\begin{array}{l}\text { Obiri et al., USA, } \\
2011\end{array}$ & PEP +/- mice & $\begin{array}{l}\text { Effect of glucocorticoids in } \\
\text { PEST-domain-enriched tyrosine } \\
\text { phosphatase (PEP) in bone } \\
\text { marrow derived mast cells }\end{array}$ & $\begin{array}{l}\text { Glucocorticoid increased PEP expression in mast } \\
\text { cells and only partially inhibited anaphylaxis. } \\
\text { Glucocorticoid potently inhibited anaphylaxis when } \\
\text { combined with the PEP inhibitor }\end{array}$ \\
\hline $\begin{array}{l}\text { Croxtall et al., } \\
2000\end{array}$ & $\begin{array}{l}\text { A549 human } \\
\text { adenocarcinoma } \\
\text { cell line }\end{array}$ & $\begin{array}{l}\text { Assess the rapidity changes } \\
\text { induced by dexamethasone and } \\
\text { the mechanism of action }\end{array}$ & $\begin{array}{l}\text { Dexamethasone, inhibits the activation of AA release } \\
\text { by EGF by a mechanism without the involvement } \\
\text { of the suppression of cPLA } 2 \text { expression. Blockade of } \\
\text { signal activation by dexamethasone was delectable } \\
\text { within } 5 \text { to } 10 \text { mins. The dose-dependence of this } \\
\text { inhibitory effect of dexamethasone was the same at } \\
5 \text { min and } 3 \mathrm{~h} \text {. The rapid effect of glucocorticoids is } \\
\text { mediated by occupation of glucocorticoid receptor }\end{array}$ \\
\hline $\begin{array}{l}\text { Miura et al., } \\
\text { Japan, } 1992\end{array}$ & $\begin{array}{l}\text { Rats with PCA } \\
\text { and cutaneous } \\
\text { reactions caused } \\
\text { by histamine } \\
\text { serotonin and } \\
\text { leukotriene C4 } \\
\text { elicited at the } \\
\text { same time }\end{array}$ & $\begin{array}{l}\text { Inhibitory mechanisms of } \\
\text { glucocorticoids in immediate } \\
\text { hypersensitivity reactions - } \\
\text { passive cutaneous anaphylaxis } \\
\text { (PCA) mediated by IgE } \\
\text { antibodies and cutaneous } \\
\text { reactions caused by histamine } \\
\text { serotonin and leukotriene C4 }\end{array}$ & $\begin{array}{l}\text { Hydrocortisone, prednisolone and dexamethasone, } \\
\text { inhibited all these reactions significantly. Hydrocortisone } \\
\text { given 1-4 and } 12 \text { hours inhibited PCA significantly. } \\
\text { Maximum inhibition observed at } 2 \text { hours. Maximum } \\
\text { inhibitions of histamine, serotonin and LTC4-induced } \\
\text { cutaneous reactions observed at } 2 \text { hours. Prednisolone } \\
\text { inhibited PCA biphasically at } 24 \text { and } 8-12 \text { hours. } \\
\text { Dexamethasone inhibited PCA persistently between } 2 \text { to } \\
12 \text { hours and maximally at } 4 \text { hours }\end{array}$ \\
\hline $\begin{array}{l}\text { Rong \& Zhao- } \\
\text { Gui, Changsha, } \\
1989\end{array}$ & $\begin{array}{l}\text { Guinea pigs } \\
\text { heart }\end{array}$ & $\begin{array}{l}\text { The protective effect of } \mathrm{H} 1 \\
\& \mathrm{H} 2 \text { antagonists, adenosine } \\
\text { and hydrocortisone on cardiac } \\
\text { anaphylaxis }\end{array}$ & $\begin{array}{l}\text { Hydrocortisone delayed the onset of arrhythmias and } \\
\text { significantly reduced the duration of arrhythmias. } \\
\text { When histamine receptor antagonists are used with } \\
\text { hydrocortisone, a good protective effect can be achieved }\end{array}$ \\
\hline $\begin{array}{l}\text { Guhlmann et al., } \\
\text { Germany, } 1989\end{array}$ & $\begin{array}{l}\text { Guinea pigs } \\
\text { suffering from } \\
\text { anaphylactic } \\
\text { shock }\end{array}$ & & $\begin{array}{l}\text { There was a lack of effect of dexamethasone on } \\
\text { anaphylactic LTC4 generation in vivo }\end{array}$ \\
\hline $\begin{array}{l}\text { Inagaki et al., } \\
\text { Japan, } 1987\end{array}$ & $\begin{array}{l}\text { Rats injected } \\
\text { with Ascaris } \\
\text { suum extract } \\
\text { serum }\end{array}$ & $\begin{array}{l}\text { Effect of hydrocortisone, } \\
\text { prednisolone and dexamethasone } \\
\text { on IgE antibody-mediated } \\
\text { homologous passive cutaneous } \\
\text { anaphylaxis (PCA) }\end{array}$ & $\begin{array}{l}\text { Injection sites were evaluated } 30 \text { minutes after } \\
\text { injection. Glucocorticoids inhibited the PCA dose- } \\
\text { dependently. They also inhibited the skin reactions } \\
\text { caused by histamine, serotonin and LTC } 4 \text { and } \\
\text { reduced vascular permeability }\end{array}$ \\
\hline \multirow[t]{2}{*}{$\begin{array}{l}\text { King et al., USA, } \\
1984\end{array}$} & \multirow[t]{2}{*}{$\begin{array}{l}\text { Outbred Wistar } \\
\text { rats }\end{array}$} & \multirow[t]{2}{*}{$\begin{array}{l}\text { Effect of glucocorticoids on } \\
\text { intestinal anaphylaxis in the rat }\end{array}$} & $\begin{array}{l}\text { Manifestations of anaphylaxis were abolished in rats } \\
\text { previously treated with corticosteroids } 48 \text { and } 24 \text { before }\end{array}$ \\
\hline & & & $\begin{array}{l}\text { This was associated with depletion of RMCP-II and } \\
\text { of MMC from the intestinal mucosa detectable at } \\
4-24 \text { hours after treatment }\end{array}$ \\
\hline $\begin{array}{l}\text { Andersson } \\
\& \text { Brattsand, } \\
\text { Sweden, } 1982\end{array}$ & $\begin{array}{l}\text { Guinea-pigs } \\
\text { sensitized to } \\
\text { two ovalbumin } \\
\text { regimens }\end{array}$ & $\begin{array}{l}\text { Effect of budesonide and } \\
\text { hydrocortisone on histamine } \\
\text { release from anaphylactically- } \\
\text { shocked chopped lung } \\
\text { fragments }\end{array}$ & $\begin{array}{l}\text { Budesonide pretreatment reduced the capacity of } \\
\text { anaphylactically-challenged chopped lung tissue to } \\
\text { release histamine }\end{array}$ \\
\hline
\end{tabular}




\section{References}

1. Johansson SG, Bieber T, Dahl R, Friedmann PS, Lanier BQ, Lockey $\mathrm{RF}$, et al. Revised nomenclature for allergy for global use: Report of the Nomenclature Review Committee of the World Allergy Organization, October 2003. J Allergy Clin Immunol. 2004;113(5):832-6.

2. Sampson HA, Munoz-Furlong A, Campbell RL, Adkinson NF, Jr., Bock SA, Branum A, et al. Second symposium on the definition and management of anaphylaxis: summary report--second National Institute of Allergy and Infectious Disease / Food Allergy and Anaphylaxis Network symposium. Ann Emerg Med. 2006;47(4):373-80.

3. Sampson HB, Burks AW. Adverse reactions to foods. In: Middleton's allergy: principles and practice. Adkinson NF Jr B, Busse WW, Holgate ST, Lemanske RF Jr, Simons FER, editor. Mosby Elsevier Inc. 2009;1139-67.

4. Lieberman P, Camargo CA, Jr., Bohlke K, Jick H, Miller RL, Sheikh A, et al. Epidemiology of anaphylaxis: findings of the American College of Allergy, Asthma and Immunology Epidemiology of Anaphylaxis Working Group. Ann Allergy Asthma Immunol. 2006;97(5):596-602.

5. Bohlke K, Davis RL, DeStefano F, Marcy SM, Braun MM, Thompson RS, et al. Epidemiology of anaphylaxis among children and adolescents enrolled in a health maintenance organization. J Allergy Clin Immunol. 2004;113(3):536-42.

6. Yocum MW, Butterfield JH, Klein JS, Volcheck GW, Schroeder DR, Silverstein MD. Epidemiology of anaphylaxis in Olmsted County: A population-based study. J Allergy Clin Immunol. 1999;104(2 Pt 1):452-6.

7. Mullins RJ. Anaphylaxis: risk factors for recurrence. Clin Exp Allergy. 2003;33(8):1033-40.

8. Simons FE, Ardusso LR, Bilo MB, Cardona V, Ebisawa M, ElGamal YM, et al. International consensus on (ICON) anaphylaxis. World Allergy Organ J. 2014;7(1):9.

9. Decker WW, Campbell RL, Manivannan V, Luke A, St Sauver JL, Weaver A, et al. The etiology and incidence of anaphylaxis in Rochester, Minnesota: a report from the Rochester Epidemiology Project. J Allergy Clin Immunol. 2008;122(6):1161-5.

10. Duval D, Durant S, Homo-Delarche F. Non-genomic effects of steroids. Interactions of steroid molecules with membrane structures and functions. Biochim Biophys Acta. 1983;737(3-4):409-42.

11. Simons FE. Anaphylaxis. J Allergy Clin Immunol. 2010;125(2 Suppl 2):S161-81.

12. Gaspar A, Santos N, Piedade S, Santa-Marta C, Pires G, Sampaio $\mathrm{G}$, et al. One-year survey of paediatric anaphylaxis in an allergy department. Eur Ann Allergy Clin Immunol. 2015;47(6):197-205.

13. Campbell RL, Li JT, Nicklas RA, Sadosty AT, Members of the Joint Task F, Practice Parameter W. Emergency department diagnosis and treatment of anaphylaxis: a practice parameter. Ann Allergy Asthma Immunol. 2014;113(6):599-608.

14. Simons FE. Anaphylaxis: Recent advances in assessment and treatment. J Allergy Clin Immunol. 2009;124(4):625-36; quiz 37-8.

15. Simons FE, Ardusso LR, Bilo MB, El-Gamal YM, Ledford DK, Ring J, et al. World allergy organization guidelines for the assessment and management of anaphylaxis. World Allergy Organ J. 2011;4(2):13-37.

16. Gaeta TJ, Clark S, Pelletier AJ, Camargo CA. National study of US emergency department visits for acute allergic reactions, 1993 to 2004. Ann Allergy Asthma Immunol. 2007;98(4):360-5.
17. Clark S, Long AA, Gaeta TJ, Camargo CA, Jr. Multicenter study of emergency department visits for insect sting allergies. J Allergy Clin Immunol. 2005;116(3):643-9.

18. Clark S, Bock SA, Gaeta TJ, Brenner BE, Cydulka RK, Camargo $\mathrm{CA}$, et al. Multicenter study of emergency department visits for food allergies. J Allergy Clin Immunol. 2004;113(2):347-52.

19. Choo KJ, Simons FE, Sheikh A. Glucocorticoids for the treatment of anaphylaxis. Evid Based Child Health. 2013;8(4):1276-94.

20. Samant SA, Campbell RL, Li JT. Anaphylaxis: diagnostic criteria and epidemiology. Allergy Asthma Proc. 2013;34(2):115-9.

21. Peavy RD, Metcalfe DD. Understanding the mechanisms of anaphylaxis. Curr Opin Allergy Clin Immunol. 2008;8(4):310-5.

22. Metcalfe DD, Peavy RD, Gilfillan AM. Mechanisms of mast cell signaling in anaphylaxis. J Allergy Clin Immunol. 2009;124(4):63946; quiz 47-8.

23. Cheifetz A, Smedley M, Martin S, Reiter M, Leone G, Mayer L, et al. The incidence and management of infusion reactions to infliximab: a large center experience. Am J Gastroenterol. 2003;98(6):1315-24.

24. Zanoni G, Puccetti A, Dolcino M, Simone R, Peretti A, Ferro $A$, et al. Dextran-specific IgG response in hypersensitivity reactions to measles-mumps-rubella vaccine. J Allergy Clin Immunol. 2008;122(6):1233-5.

25. Kishimoto TK, Viswanathan K, Ganguly T, Elankumaran S, Smith $\mathrm{S}$, Pelzer K, et al. Contaminated heparin associated with adverse clinical events and activation of the contact system. N Engl J Med. 2008;358(23):2457-67.

26. Khodoun M, Strait R, Orekov T, Hogan S, Karasuyama H, Herbert $\mathrm{DR}$, et al. Peanuts can contribute to anaphylactic shock by activating complement. J Allergy Clin Immunol. 2009;123(2):342-51.

27. Lenchner K, Grammer LC. A current review of idiopathic anaphylaxis. Curr Opin Allergy Clin Immunol. 2003;3(4):305-11.

28. 28. Limb SL, Starke PR, Lee CE, Chowdhury BA. Delayed onset and protracted progression of anaphylaxis after omalizumab administration in patients with asthma. J Allergy Clin Immunol. 2007;120(6):1378-81.

29. Stark BJ, Sullivan TJ. Biphasic and protracted anaphylaxis. J Allergy Clin Immunol. 1986;78(1 Pt 1):76-83.

30. Muraro A, Roberts G, Worm M, Bilo MB, Brockow K, Fernandez Rivas M, et al. Anaphylaxis: guidelines from the European Academy of Allergy and Clinical Immunology. Allergy. 2014;69(8):1026-45.

31. Simons FE, Ebisawa M, Sanchez-Borges M, Thong BY, Worm M, Tanno LK, et al. 2015 update of the evidence base: World Allergy Organization anaphylaxis guidelines. World Allergy Organ J. 2015;8(1):32.

32. Lieberman P, Nicklas RA, Oppenheimer J, Kemp SF, Lang DM, Bernstein DI, et al. The diagnosis and management of anaphylaxis practice parameter: 2010 update. J Allergy Clin Immunol. 2010;126(3):477-80e1-42.

33. Vale S, Smith J, Said M, Mullins RJ, Loh R. ASCIA guidelines for prevention of anaphylaxis in schools, pre-schools and childcare: 2015 update. J Paediatr Child Health. 2015;51(10):949-54.

34. Perino A, Galimberti M, Bilo MB, Asero R, Pezzuto F, Guidelines ACfUoAiA. Use of adrenaline in allergy. Eur Ann Allergy Clin Immunol. 2008;40(2):35-52.

35. Alrasbi M, Sheikh A. Comparison of international guidelines for the emergency medical management of anaphylaxis. Allergy. 2007;62(8):838-41.

36. Burton C, Worth A. UK Resuscitation Council guidelines on emergency treatment of anaphylactic reactions: a primary care perspective. Prim Care Respir J. 2008;17(2):60-1. 
37. Waserman S, Chad Z, Francoeur MJ, Small P, Stark D, Vander Leek TK, et al. Management of anaphylaxis in primary care: Canadian expert consensus recommendations. Allergy. 2010;65(9):1082-92.

38. Soar J, Pumphrey R, Cant A, Clarke S, Corbett A, Dawson P, et al. Emergency treatment of anaphylactic reactions - guidelines for healthcare providers. Resuscitation. 2008;77(2):157-69.

39. Russell S, Monroe K, Losek JD. Anaphylaxis management in the pediatric emergency department: opportunities for improvement. Pediatr Emerg Care. 2010;26(2):71-6.

40. van der Velden VH. Glucocorticoids: mechanisms of action and anti-inflammatory potential in asthma. Mediators Inflamm. 1998;7(4):229-37.

41. Rhen T, Cidlowski JA. Antiinflammatory action of glucocorticoids--new mechanisms for old drugs. $N$ Engl J Med. 2005;353(16):1711-23.

42. Rider LG, Hirasawa N, Santini F, Beaven MA. Activation of the mitogen-activated protein kinase cascade is suppressed by low concentrations of dexamethasone in mast cells. J Immunol. 1996;157(6):2374-80.

43. Eklund KK, Humphries DE, Xia Z, Ghildyal N, Friend DS, Gross $\mathrm{V}$, et al. Glucocorticoids inhibit the cytokine-induced proliferation of mast cells, the high affinity $\mathrm{IgE}$ receptor-mediated expression of TNF-alpha, and the IL-10-induced expression of chymases. J Immunol. 1997;158(9):4373-80.

44. Finotto S, Mekori YA, Metcalfe DD. Glucocorticoids decrease tissue mast cell number by reducing the production of the c-kit ligand, stem cell factor, by resident cells: in vitro and in vivo evidence in murine systems. J Clin Invest. 1997;99(7):1721-8.

45. Krishnan JA, Davis SQ, Naureckas ET, Gibson P, Rowe BH. An umbrella review: corticosteroid therapy for adults with acute asthma. Am J Med. 2009;122(11):977-91.

46. Oppong E, Flink N, Cato AC. Molecular mechanisms of glucocorticoid action in mast cells. Mol Cell Endocrinol. 2013;380(1-2):119-26.

47. Heiman AS, Crews FT. Hydrocortisone selectively inhibits IgE-dependent arachidonic acid release from rat peritoneal mast cells. Prostaglandins. 1984;27(2):335-43.

48. Miura T, Inagaki N, Yoshida K, Nakajima T, Nagai H, Koda A. Mechanisms for glucocorticoid inhibition of immediate hypersensitivity reactions in rats. Jpn J Pharmacol. 1992;59(1):77-87.

49. Zhou J, Li M, Sheng CQ, Liu L, Li Z, Wang Y, et al. A novel strategy for development of glucocorticoids through non-genomic mechanism. Cell Mol Life Sci. 2011;68(8):1405-14.

50. Losel R, Wehling M. Nongenomic actions of steroid hormones. Nat Rev Mol Cell Biol. 2003;4(1):46-56.

51. Buttgereit F, Straub RH, Wehling M, Burmester GR. Glucocorticoids in the treatment of rheumatic diseases: an update on the mechanisms of action. Arthritis Rheum. 2004;50(11):3408-17.

52. Croxtall JD, Choudhury Q, Flower RJ. Glucocorticoids act within minutes to inhibit recruitment of signalling factors to activated EGF receptors through a receptor-dependent, transcription-independent mechanism. Br J Pharmacol. 2000;130(2):289-98.

53. Inagaki $\mathrm{N}$, Miura $\mathrm{T}$, Nagai $\mathrm{H}$, Koda A. Inhibitory effects of glucocorticoids on increased vascular permeability caused by passive cutaneous anaphylaxis and some chemical mediators in rats. Jpn J Pharmacol. 1988;46(2):189-92.

54. Cato AC, Nestl A, Mink S. Rapid actions of steroid receptors in cellular signaling pathways. Sci STKE. 2002;2002(138):re9.
55. Liu C, Zhou J, Zhang LD, Wang YX, Kang ZM, Chen YZ, et al. Rapid inhibitory effect of corticosterone on histamine release from rat peritoneal mast cells. Horm Metab Res. 2007;39(4):273-7.

56. Manuyakorn W, Benjaponpitak S, Kamchaisatian W, Vilaiyuk S, Sasisakulporn C, Jotikasthira W. Pediatric anaphylaxis: triggers, clinical features, and treatment in a tertiary-care hospital. Asian Pac J Allergy Immunol. 2015;33(4):281-8.

57. Ko BS, Kim WY, Ryoo SM, Ahn S, Sohn CH, Seo DW, et al. Biphasic reactions in patients with anaphylaxis treated with corticosteroids. Ann Allergy Asthma Immunol. 2015;115(4):312-6.

58. Ellis AK, Day JH. Incidence and characteristics of biphasic anaphylaxis: a prospective evaluation of 103 patients. Ann Allergy Asthma Immunol. 2007;98(1):64-9.

59. Lee JM, Greenes DS. Biphasic anaphylactic reactions in pediatrics. Pediatrics. 2000;106(4):762-6.

60. Michelson KA, Monuteaux MC, Neuman MI. Glucocorticoids and Hospital Length of Stay for Children with Anaphylaxis: A Retrospective Study. J Pediatr. 2015;167(3):719-24 e1-3.

61. Grunau BE, Li J, Yi TW, Stenstrom R, Grafstein E, Wiens MO, et al. Incidence of clinically important biphasic reactions in emergency department patients with allergic reactions or anaphylaxis. Ann Emerg Med. 2014;63(6):736-44 e2.

62. Andersson P, Brattsand R. Protective effects of the glucocorticoid, budesonide, on lung anaphylaxis in actively sensitized guinea-pigs: inhibition of IgE-but not of IgG-mediated anaphylaxis. Br J Pharmacol. 1982;76(1):139-47.

63. Qiu R, Guo ZG. Protective effects of histamine H1 and H2 antagonists, adenosine and hydrocortisone on cardiac anaphylaxis. Zhongguo Yao Li Xue Bao. 1989;10(1):34-40.

64. Guhlmann A, Keppler A, Kastner S, Krieter H, Bruckner UB, Messmer K, et al. Prevention of endogenous leukotriene production during anaphylaxis in the guinea pig by an inhibitor of leukotriene biosynthesis (MK-886) but not by dexamethasone. J Exp Med. 1989;170(6):1905-18.

65. King SJ, Miller HR, Newlands GF, Woodbury RG. Depletion of mucosal mast cell protease by corticosteroids: effect on intestinal anaphylaxis in the rat. Proc Natl Acad Sci USA. 1985;82(4):1214-8.

66. Obiri DD, Flink N, Maier JV, Neeb A, Maddalo D, Thiele W, et al. PEST-domain-enriched tyrosine phosphatase and glucocorticoids as regulators of anaphylaxis in mice. Allergy. 2012;67(2):175-82.

67. Simons FE. Emergency treatment of anaphylaxis. BMJ. 2008;336(7654):1141-2.

68. Simons FE. Pharmacologic treatment of anaphylaxis: can the evidence base be strengthened? Curr Opin Allergy Clin Immunol. 2010;10(4):384-93.

69. Lieberman P. Biphasic anaphylactic reactions. Ann Allergy Asthma Immunol. 2005;95(3):217-26; quiz 26,58.

70. Asai Y, Yanishevsky Y, Clarke A, La Vieille S, Delaney JS, Alizadehfar R, et al. Rate, triggers, severity and management of anaphylaxis in adults treated in a Canadian emergency department. Int Arch Allergy Immunol. 2014;164(3):246-52.

71. Chrousos G, Pavlaki AN, Magiakou MA. Glucocorticoid Therapy and Adrenal Suppression. In: De Groot LJ, Beck-Peccoz P, Chrousos G, Dungan K, Grossman A, Hershman JM, et al., editors. Endotext. South Dartmouth (MA)2000. 